\title{
Microbial challenge test of a novel epoprostenol sodium formulation
}

\author{
This article was published in the following Dove Press journal: \\ Drug Design, Development and Therapy \\ 10 August 2017 \\ Number of times this article has been viewed
}

\section{Dirk Bandilla' \\ Marcel Goverde ${ }^{2}$ \\ Paolo Giudici' \\ Olivier Lambert'}

'Actelion Pharmaceuticals Ltd., Allschwil, ${ }^{2}$ MGP Consulting $\mathrm{GmbH}$,

Binningen, Switzerland
Correspondence: Dirk Bandilla Actelion Pharmaceuticals Ltd., Gewerbestrasse 16, $\mathrm{CH}-4123$ Allschwil, Switzerland Tel +4I 6I 5656565 Fax +4I 6I 5656406 Email dirk.bandilla@actelion.com
Aim: The aim of the current study was to present a comprehensive display of antimicrobial activity of a novel epoprostenol sodium formulation with respect to seven different microorganisms, two levels of inoculation $\left(10^{2}-10^{3}\right.$ colony forming units $[\mathrm{CFU}] / \mathrm{mL}$ and $\left.10^{5}-10^{6} \mathrm{CFU} / \mathrm{mL}\right)$, two diluents (sterile water for injection [SWI] and sterile saline [sodium chloride $0.9 \%$ ] for injection [SSI]), two concentrations $(3,000 \mathrm{ng} / \mathrm{mL}$ and $15,000 \mathrm{ng} / \mathrm{mL})$, and seven different storage time points at two temperatures (up to 10 days at $2^{\circ} \mathrm{C}-8^{\circ} \mathrm{C}$ and $20^{\circ} \mathrm{C}-25^{\circ} \mathrm{C}$ ).

Materials and methods: Antimicrobial activity was evaluated for, 1) solutions at 3,000 ng/mL inoculated with $10^{2}-10^{3} \mathrm{CFU} / \mathrm{mL}$ and $10^{5}-10^{6} \mathrm{CFU} / \mathrm{mL}$; and 2) solutions at $15,000 \mathrm{ng} / \mathrm{mL}$ inoculated with $10^{2}-10^{3} \mathrm{CFU} / \mathrm{mL}$ and $10^{5}-10^{6} \mathrm{CFU} / \mathrm{mL}$. All solutions were stored for up to 10 days at $2^{\circ} \mathrm{C}-8^{\circ} \mathrm{C}$ and $20^{\circ} \mathrm{C}-25^{\circ} \mathrm{C}$. Solutions were prepared by reconstitution and further dilution of an epoprostenol sodium formulation using SWI or SSI. Antimicrobial activity was measured after inoculation with seven species of bacteria, yeast, and mold.

Results: For all solutions, after 10 days, no microbial growth with respect to initial inoculum was observed, with the exception of a few early time points when using SWI as diluent. Some microorganisms died off completely, whereas others remained stable overall or returned to initial levels. Prior to decreasing, some microorganisms displayed a slight initial increase, presumed to be caused by breakup of clusters. Storage temperature had a negligible influence on the results, whereas choice of diluent (SSI or SWI) impacted growth kinetics in that SSI had a greater antimicrobial effect than SWI.

Conclusion: Upon reconstitution and further dilution of the novel epoprostenol formulation to concentrations of $3,000 \mathrm{ng} / \mathrm{mL}$ and $15,000 \mathrm{ng} / \mathrm{mL}$ with SWI or SSI, the resulting solutions did not support growth of the tested microorganisms when stored at $2^{\circ} \mathrm{C}-8^{\circ} \mathrm{C}$ or $20^{\circ} \mathrm{C}-25^{\circ} \mathrm{C}$ for up to 10 days.

Keywords: epoprostenol, preservative effectiveness, stability, microbial challenge

\section{Introduction}

Pulmonary arterial hypertension is a severe disease characterized by progressive elevation of pulmonary arterial pressure and pulmonary vascular resistance, leading to right ventricular failure and death. ${ }^{1}$ Patients with pulmonary arterial hypertension require lifelong therapy. ${ }^{2}$ Treatment of pulmonary arterial hypertension is currently based on three key pathways, one of them being the prostaglandin $\mathrm{I}_{2}$ pathway, which is also the first pathway for which a therapy of pulmonary arterial hypertension became available via continuous intravenous infusion of epoprostenol. We recently reported on the chemical stability of Veletri ${ }^{\circledR}$ (Actelion Pharmaceuticals Ltd., Allschwil, Switzerland), a sterile-manufactured, lyophilized formulation of epoprostenol sodium containing arginine and sucrose as excipients (epoprostenol sodium AS). ${ }^{3}$ The formulation is intended for continuous intravenous administration upon reconstitution 
and further dilution with either sterile water for injection (SWI) or sterile saline (sodium chloride $0.9 \%$ ) for injection (SSI). Resulting solutions demonstrated prolonged stability at different temperatures compared with previously developed epoprostenol formulations. ${ }^{4,5}$ Epoprostenol sodium AS is indicated for the intravenous, long-term treatment of pulmonary arterial hypertension and has become available in two dose strengths $(0.5 \mathrm{mg}$ and $1.5 \mathrm{mg})$ in several countries since 2011. In order to reduce a potential risk of infection during intravenous administration, the epoprostenol sodium AS solution is filtered through a $0.2 \mu \mathrm{m}$ filter. The filter is replaced regularly to further increase patients' safety. In addition to this filter, knowledge of the potential antimicrobial activity of any formulation intended for parenteral administration is paramount in order to minimize the risk of infections for patients during administration. This publication describes an investigation on the antimicrobial activity of epoprostenol sodium AS solution upon reconstitution and further dilution with either SWI or SSI. Antimicrobial properties of the product can be determined using the challenge test described in the United States Pharmacopeia (USP) 51, in which microorganisms are deliberately added to solutions, which are then stored under controlled temperature and humidity conditions. ${ }^{6}$ At predefined time points, the amount of each microorganism is counted. ${ }^{6-8}$ One potential source of microbial contamination for products requiring reconstitution could be contamination introduced from the human skin, especially the fingers, or from the environment. Human skin typically contains between $10^{3}$ colony forming units (CFU) $/ \mathrm{cm}^{2}$ and $10^{6} \mathrm{CFU} / \mathrm{cm}^{2}$ of microbes, the number and species of which vary across different regions of the body. ${ }^{9-12}$ Human skin is not a suitable location for microbial growth since it is subjected to regular desiccation, which especially reduces the transient micro flora. In particular, the dry regions, such as hands, have a lower number of CFU $/ \mathrm{cm}^{2}$ than humid regions or areas of skin with apocrine glands. Indeed, most skin microorganisms (especially the resident microflora) are associated with apocrine glands. The most common human skin species are gram-positive bacteria from the genus Staphylococcus, Propionibacterium, Micrococcus, and Corynebacterium. ${ }^{11,13}$ Consequently, the number of microorganisms potentially added by the human skin should be low (probably $<10^{2} \mathrm{CFU}$ ), especially when hands are washed and disinfected correctly prior to any handling of the formulation. ${ }^{14-17}$

The focus of our earlier publications was the chemical stability of epoprostenol sodium, which was demonstrated to be superior to previous formulations. ${ }^{5}$ Some results for antimicrobial activity were reported for the $0.5 \mathrm{mg}$ dose strength upon reconstitution (leading to a concentration of $100,000 \mathrm{ng} / \mathrm{mL}$ ) and further dilution (leading to a concentration of 3,000 ng/mL) using an inoculum of $<10^{1} \mathrm{CFU} / \mathrm{mL}$. In the present study, a more in-depth comprehensive display of antimicrobial activity of epoprostenol sodium AS for both the $0.5 \mathrm{mg}$ and the $1.5 \mathrm{mg}$ dose strength is provided, with respect to concentration, temperature, and diluents. Unlike the previous publication, where a low inoculum had been evaluated, the focus is now on higher inocula in order to mimic a worst-case introduction of microorganisms from the human skin $\left(10^{2}-10^{3} \mathrm{CFU} / \mathrm{mL}\right) ;^{18}$ the inoculum proposed in the relevant pharmacopeia chapter USP $51\left(10^{5}-10^{6} \mathrm{CFU} / \mathrm{mL}\right)$ is also evaluated. ${ }^{6}$ It has now become a standard practice in many centers globally that concentrations $\geq 3,000 \mathrm{ng} / \mathrm{mL}$ and $<15,000 \mathrm{ng} / \mathrm{mL}$ are prepared from the $0.5 \mathrm{mg}$ dose strength, whereas concentrations $\geq 15,000 \mathrm{ng} / \mathrm{mL}$ are prepared from the $1.5 \mathrm{mg}$ dose strength. Just as the $\mathrm{pH}$ of a 3,000 ng/mL solution will differ from a 15,000 ng/mL solution, so may be the antimicrobial activity. For this purpose, each dose strength was first reconstituted with SWI or SSI. Using the same diluents, the $0.5 \mathrm{mg}$ vials were then diluted further to $3,000 \mathrm{ng} / \mathrm{mL}$ and the $1.5 \mathrm{mg}$ vials to $15,000 \mathrm{ng} / \mathrm{mL}$. The resulting solutions (hereafter referred to as epoprostenol sodium AS solutions) were subsequently individually inoculated with seven different microorganisms, followed by storage for up to 10 days at $2^{\circ} \mathrm{C}-8^{\circ} \mathrm{C}$ and at $20^{\circ} \mathrm{C}-25^{\circ} \mathrm{C}$. A storage time for up to 10 days was selected based on the previous investigations, which had shown that the maximum shelf-life of epoprostenol sodium AS solutions depending on the final concentration was up to 10 days. $^{4}$ After defined incubation times, the microbial counts were determined and $\log$ reductions were calculated. Prior to the microbial challenge test, a method verification study according to USP 51 was conducted. ${ }^{6}$

\section{Materials and methods Setting of the study}

All antimicrobial activity measurements were performed between June 2012 and August 2012 in the laboratories of AAIPharma Analytical Services (Edison, NJ, USA) based on predefined protocols under the responsibility of Actelion Pharmaceuticals Ltd.

\section{Formulation}

Epoprostenol sodium AS is a sterile-manufactured, lyophilized powder for reconstitution, packaged in $10 \mathrm{~mL}$ glass vials with $20 \mathrm{~mm}$ rubber stoppers. In addition to the active 
pharmaceutical ingredient epoprostenol sodium at either $0.5 \mathrm{mg}$ or $1.5 \mathrm{mg} / \mathrm{vial}$, the formulation contains L-arginine at $50 \mathrm{mg} /$ vial (buffering agent), sucrose at $100 \mathrm{mg} /$ vial (bulking agent), and sodium hydroxide (for $\mathrm{pH}$ adjustment).

\section{Sample reconstitution}

For preparation of the $3,000 \mathrm{ng} / \mathrm{mL}$ concentration, one vial of epoprostenol sodium AS $0.5 \mathrm{mg}$ was reconstituted with $5.0 \mathrm{~mL}$ of diluent (SSI or SWI); $3.0 \mathrm{~mL}$ of diluent was withdrawn from the reconstituted vial, transferred into a separate sterile container, and further diluted to $100 \mathrm{~mL}$ with the respective diluent. This was followed by inoculation with $100 \mu \mathrm{L}$ of the respective microorganism. The procedure was repeated for each microorganism.

For preparation of the $15,000 \mathrm{ng} / \mathrm{mL}$ concentration, one vial of epoprostenol sodium AS $1.5 \mathrm{mg}$ was reconstituted with $5.0 \mathrm{~mL}$ of diluent (SSI or SWI) and the entire content was transferred into a separate sterile container; this was further diluted to $100 \mathrm{~mL}$ with the respective diluent, followed by inoculation with $100 \mu \mathrm{L}$ of the respective microorganism. The procedure was repeated for each microorganism.

\section{$\mathrm{pH}$ measurements}

All $\mathrm{pH}$ measurements were performed using a Uniprobe $\mathrm{Pt}$ 1,000 glass electrode (Metrohm, Zofingen, Switzerland).

\section{Antimicrobial property testing}

The five microorganisms listed in USP chapter 51 were investigated in this study, namely, Staphylococcus aureus, Pseudomonas aeruginosa, Escherichia coli, Candida albicans, and Aspergillus brasiliensis. ${ }^{5}$ In addition, Clostridium sporogenes, an anaerobic, gram-positive, rodshaped, spore-producing bacterium, and Micrococcus luteus, a typical human skin bacterium, were studied. Cultures of the bacteria S. aureus (ATCC 6538), P. aeruginosa (ATCC 9027), E. coli (ATCC 8739), C. sporogenes (ATCC 11437), M. luteus (ATCC 10240), the yeast C. albicans (ATCC 10231), and the mold A. brasiliensis (ATCC 16404) were prepared as per manufacturer's instructions (Remel QuantiCult Plus; Thermo Fisher Scientific, Waltham, MA, USA). All cultures were used within 24 hours of preparation. An initial plate count using each microbial suspension was performed to confirm appropriate levels of microorganisms: for this, each microbial suspension was plated into sterile Petri dishes in duplicate. Using the pour plate method, bacteria were plated with tempered casein soybean digest agar containing $0.5 \%$ polysorbate 80 and $0.07 \%$ lecithin (USP 62). ${ }^{6}$ Yeasts and molds were plated with tempered
Sabouraud dextrose agar (USP 62)..$^{6}$ Plates were incubated for $3-5$ days at $30^{\circ} \mathrm{C}-35^{\circ} \mathrm{C}$ for bacteria and $20^{\circ} \mathrm{C}-25^{\circ} \mathrm{C}$ for yeast and molds $(C$. sporogenes was incubated under anaerobic conditions). Readouts of the number of CFU per Petri dish were performed using a Quebec Colony Counter (Reichert Analytical Instruments, Depew, NY, USA).

\section{Suitability test}

For both epoprostenol sodium AS solutions $(3,000 \mathrm{ng} / \mathrm{mL}$ and $15,000 \mathrm{ng} / \mathrm{mL}$ ), a suitability test was performed to ensure the validity of the test method. Sample reconstitution was performed as described earlier. Pure diluent (SSI and SWI) served as positive controls. For each sample and positive control, a 1:10 dilution was made by adding $1 \mathrm{~mL}$ of sample solution to $9 \mathrm{~mL}$ of Letheen broth ( $1 \%$ meat peptone, $0.5 \%$ beef extract, $0.5 \%$ polysorbate $80,0.5 \% \mathrm{NaCl}$, and $0.07 \%$ lecithin). ${ }^{19}$ Next, all samples and positive controls were incubated with $\sim 100 \mu \mathrm{L}$ of the respective inoculum for 10-15 minutes. Plating was performed as described earlier. A recovery rate of $50 \%-200 \%$ of the samples with epoprostenol sodium AS solution compared with the positive controls served as the acceptance criterion.

\section{Test procedure}

Samples were stored at either $2^{\circ} \mathrm{C}-8^{\circ} \mathrm{C}$ or $20^{\circ} \mathrm{C}-25^{\circ} \mathrm{C}$. At the predefined time points (Table 1), a $1 \mathrm{~mL}$ aliquot was removed and plated as described. Two different challenge concentrations $\left(10^{2}-10^{3} \mathrm{CFU} / \mathrm{mL}\right.$ and $\left.10^{5}-10^{6} \mathrm{CFU} / \mathrm{mL}\right)$ were used for each product concentration and storage condition. For both concentrations of epoprostenol sodium AS solution, both reconstitution diluents, both storage temperatures, both microbial challenge concentrations, and each microorganism, seven different time points were analyzed (Table 1). All analyses were performed in duplicate.

\section{Acceptance criteria}

Since there are no compendial acceptance criteria for reconstituted products, we used two different approaches for interpretation of the results, as suggested by Metcalfe, ${ }^{18}$ namely, $\log$ reductions and growth curves. The log reductions were calculated as follows:

$$
\begin{aligned}
\text { Log reduction } & =\log _{10} \mathrm{CFU} \text { initial count } \\
& -\log _{10} \mathrm{CFU} \text { at time } \mathrm{x}
\end{aligned}
$$

In accordance with USP 51, no growth was defined as when the $\log$ reduction was not $>0.5 \log _{10}$ units higher than the previous value. ${ }^{6}$ We defined previous value as the initial 
Table I Testing procedure summary of all combinations: epoprostenol sodium AS concentration, storage temperature, reconstitution diluent, challenge concentration, and time points

\begin{tabular}{|c|c|c|c|c|c|c|c|c|c|c|}
\hline \multirow{2}{*}{$\begin{array}{l}\begin{array}{l}\text { Epoprostenol } \\
\text { concentration }(\mathrm{mg})\end{array} \\
0.5\end{array}$} & \multirow{2}{*}{$\begin{array}{l}\begin{array}{l}\text { Storage } \\
\text { temperature }\left({ }^{\circ} \mathrm{C}\right)\end{array} \\
2-8\end{array}$} & \multirow{2}{*}{$\begin{array}{l}\text { Diluent } \\
\text { SSI }\end{array}$} & \multirow{2}{*}{$\begin{array}{l}\text { Challenge concentration } \\
\text { (CFU/mL) } \\
10^{2}-10^{3}\end{array}$} & \multicolumn{7}{|c|}{ Time points } \\
\hline & & & & $0 \mathrm{~h}$ & $6 \mathrm{~h}$ & $24 \mathrm{~h}$ & $48 \mathrm{~h}$ & $72 \mathrm{~h}$ & $5 d$ & $10 \mathrm{~d}$ \\
\hline & $20-25$ & & & & & & & & & \\
\hline & $2-8$ & SWI & & & & & & & & \\
\hline & $20-25$ & & & & & & & & & \\
\hline & $2-8$ & SSI & $10^{5}-10^{6}$ & & & & & & & \\
\hline & $20-25$ & & & & & & & & & \\
\hline & $2-8$ & SWI & & & & & & & & \\
\hline & $20-25$ & & & & & & & & & \\
\hline \multirow[t]{8}{*}{1.5} & $2-8$ & SSI & $10^{2}-10^{3}$ & $0 \mathrm{~h}$ & $6 \mathrm{~h}$ & $24 \mathrm{~h}$ & $48 \mathrm{~h}$ & $72 \mathrm{~h}$ & $5 \mathrm{~d}$ & $10 \mathrm{~d}$ \\
\hline & $20-25$ & & & & & & & & & \\
\hline & $2-8$ & SWI & & & & & & & & \\
\hline & $20-25$ & & & & & & & & & \\
\hline & $2-8$ & SSI & $10^{5}-10^{6}$ & & & & & & & \\
\hline & $20-25$ & & & & & & & & & \\
\hline & $2-8$ & SWI & & & & & & & & \\
\hline & $20-25$ & & & & & & & & & \\
\hline
\end{tabular}

Abbreviations: AS, arginine sucrose; CFU, colony forming units; SSI, sterile saline (sodium chloride $0.9 \%$ ) for injection; SWI, sterile water for injection; h, hours; d, days.

time point since this was the time point where a potential microbial contamination could occur. Microbial growth in growth curves is displayed by plotting incubation time on the $x$-axis and $\log \mathrm{CFU} / \mathrm{mL}$ on the $y$-axis. Even when fulfilling the USP 51 requirements, such growth curves can nevertheless illustrate the onset of microbial growth. ${ }^{18}$

\section{Results}

\section{$\mathrm{pH}$ measurements}

Epoprostenol sodium AS solutions at $3,000 \mathrm{ng} / \mathrm{mL}$ prepared in SSI and SWI had a pH of 11.0. At $15,000 \mathrm{ng} / \mathrm{mL}$, epoprostenol sodium AS solution prepared in SSI had a $\mathrm{pH}$ of 11.2 and in SWI had a pH of 11.4. All pH values therefore fell into the range of $\mathrm{pH}$ values of reconstituted and further diluted epoprostenol sodium AS solutions published previously. ${ }^{4}$

\section{Suitability test}

For both epoprostenol sodium AS solutions, a suitability test was performed. All recoveries were within the given acceptance criterion (recovery rate of $50 \%-200 \%$ ) for each of the seven microorganisms (Tables 2 and 3). Thus, it was shown

Table 2 Recovery rate from the suitability test for epoprostenol sodium AS $0.5 \mathrm{mg}$ reconstituted and diluted to $3,000 \mathrm{ng} / \mathrm{mL}$ with SSI and SWI

\begin{tabular}{|c|c|c|c|c|c|}
\hline \multirow[t]{2}{*}{ Microorganism } & \multirow[t]{2}{*}{ Test } & \multicolumn{2}{|l|}{ SSI } & \multicolumn{2}{|l|}{ SWI } \\
\hline & & Average CFU & Recovery rate (\%) & Average CFU & Recovery rate (\%) \\
\hline \multirow[t]{2}{*}{ S. aureus } & Product challenge & 35 & 94.6 & 32 & 86.5 \\
\hline & Inoculum control & 37 & & 37 & \\
\hline \multirow[t]{2}{*}{ P. aeruginosa } & Product challenge & 38 & 88.4 & 42 & 97.7 \\
\hline & Inoculum control & 43 & & 43 & \\
\hline \multirow[t]{2}{*}{ E. coli } & Product challenge & 36 & 90.0 & 39 & 97.5 \\
\hline & Inoculum control & 40 & & 40 & \\
\hline \multirow[t]{2}{*}{ C. albicans } & Product challenge & 46 & 92.0 & 46 & 92.0 \\
\hline & Inoculum control & 50 & & 50 & \\
\hline \multirow[t]{2}{*}{ A. brasiliensis } & Product challenge & 27 & 93.1 & 25 & 86.2 \\
\hline & Inoculum control & 29 & & 29 & \\
\hline \multirow[t]{2}{*}{ M. luteus } & Product challenge & 42 & 95.5 & 39 & 88.6 \\
\hline & Inoculum control & 44 & & 44 & \\
\hline \multirow[t]{2}{*}{ C. sporogenes } & Product challenge & 45 & 102.3 & 40 & 90.9 \\
\hline & Inoculum control & 44 & & 44 & \\
\hline
\end{tabular}

Abbreviations: SSI, sterile saline (sodium chloride $0.9 \%$ ) for injection; SWI, sterile water for injection; CFU, colony forming units; S. aureus, Staphylococcus aureus; P. aeruginosa, Pseudomonas aeruginosa; E. coli, Escherichia coli; C. albicans, Candida albicans; A. brasiliensis, Aspergillus brasiliensis; M. luteus, Micrococcus luteus; C. sporogenes, Clostridium sporogenes. 
Table 3 Recovery rate from the suitability test for epoprostenol sodium AS I.5 $\mathrm{mg}$ reconstituted and diluted to $15,000 \mathrm{ng} / \mathrm{mL}$ with SSI and SWI

\begin{tabular}{|c|c|c|c|c|c|}
\hline \multirow[t]{2}{*}{ Microorganism } & \multirow[t]{2}{*}{ Test } & \multicolumn{2}{|l|}{ SWI } & \multicolumn{2}{|l|}{ SSI } \\
\hline & & Average CFU & Recovery rate (\%) & Average CFU & Recovery rate (\%) \\
\hline \multirow[t]{2}{*}{ S. aureus } & Product challenge & 33 & 89.2 & 31 & 83.8 \\
\hline & Inoculum control & 37 & & 37 & \\
\hline \multirow[t]{2}{*}{ P. aeruginosa } & Product challenge & 40 & 93.0 & 40 & 93.0 \\
\hline & Inoculum control & 43 & & 43 & \\
\hline \multirow[t]{2}{*}{ E. coli } & Product challenge & 39 & 97.5 & 37 & 92.5 \\
\hline & Inoculum control & 40 & & 40 & \\
\hline \multirow[t]{2}{*}{ C. albicans } & Product challenge & 44 & 88.0 & 45 & 90.0 \\
\hline & Inoculum control & 50 & & 50 & \\
\hline \multirow[t]{2}{*}{ A. brasiliensis } & Product challenge & 25 & 86.2 & 24 & 82.8 \\
\hline & Inoculum control & 29 & & 29 & \\
\hline \multirow[t]{2}{*}{ M. luteus } & Product challenge & 38 & 86.4 & 39 & 88.6 \\
\hline & Inoculum control & 44 & & 44 & \\
\hline \multirow[t]{2}{*}{ C. sporogenes } & Product challenge & 34 & 77.3 & 42 & 95.5 \\
\hline & Inoculum control & 44 & & 44 & \\
\hline
\end{tabular}

Abbreviations: SSI, sterile saline (sodium chloride 0.9\%) for injection; SWI, sterile water for injection; CFU, colony forming units; S. aureus, Staphylococcus aureus; P. aeruginosa, Pseudomonas aeruginosa; E. coli, Escherichia coli; C. albicans, Candida albicans; A. brasiliensis, Aspergillus brasiliensis; M. luteus, Micrococcus luteus; C. sporogenes, Clostridium sporogenes.

that the method used was suitable for both dose strengths and for all microorganisms used.

\section{Low-level challenge tests}

The log reductions for the low-level challenge tests (ie, incubation with $10^{2}-10^{3} \mathrm{CFU}$ ) of the epoprostenol sodium AS solutions are summarized in Tables 4 and 5. Growth curves are displayed in Figures 1 and 2.

For the low-level challenge using the diluent SSI, all tests fulfilled the acceptance criterion of USP 51 at both storage temperatures (Tables 4 and 5). ${ }^{6}$ Moreover, apart from $A$. brasiliensis and $C$. sporogenes, the five remaining microorganisms died off within 72 hours, with $P$. aeruginosa dying off almost instantaneously (Figures $1 \mathrm{~A}$ and $\mathrm{B}$ and $2 \mathrm{~A}$ and $\mathrm{B}$ ). For $A$. brasiliensis and $C$. sporogenes, especially at the elevated temperatures of $20^{\circ} \mathrm{C}-25^{\circ} \mathrm{C}$, a subtle growth at the end of the incubation period became apparent (Figures $1 \mathrm{~B}$ and $2 \mathrm{~B}$ ). One possible interpretation could be that, after 5 days of incubation, surviving microorganisms may have regained their growth possibility at both epoprostenol

Table 4 Summary of log reductions with respect to initial time point for the low-level challenge test for epoprostenol sodium AS $0.5 \mathrm{mg}$ reconstituted and diluted to $3,000 \mathrm{ng} / \mathrm{mL}$ with SSI and SWI and stored at two different temperatures $\left(2^{\circ} \mathrm{C}-8^{\circ} \mathrm{C}\right.$ and $\left.20^{\circ} \mathrm{C}-25^{\circ} \mathrm{C}\right)$

\begin{tabular}{|c|c|c|c|c|c|c|c|c|c|c|c|c|c|c|}
\hline \multirow[t]{2}{*}{ Microorganism } & $\mathbf{O h}$ & $6 \mathrm{~h}$ & $24 \mathrm{~h}$ & $48 \mathrm{~h}$ & $72 \mathrm{~h}$ & $5 \mathrm{~d}$ & $10 \mathrm{~d}$ & $\mathbf{O h}$ & $6 \mathrm{~h}$ & $24 \mathrm{~h}$ & $48 \mathrm{~h}$ & $72 \mathrm{~h}$ & $5 \mathrm{~d}$ & $10 \mathrm{~d}$ \\
\hline & \multicolumn{7}{|c|}{$2^{\circ} \mathrm{C}-8^{\circ} \mathrm{C}, \mathrm{SSI}$} & \multicolumn{7}{|c|}{$20^{\circ} \mathrm{C}-25^{\circ} \mathrm{C}, \mathrm{SSI}$} \\
\hline S. aureus & -0.1 & -0.2 & 0.6 & 1.3 & 2.9 & 2.9 & 2.9 & -0.1 & 0.3 & 2.9 & 2.9 & 2.9 & 2.9 & 2.9 \\
\hline P. aeruginosa & 0.1 & 2.8 & 2.8 & 2.8 & 2.8 & 2.8 & 2.8 & 0.1 & 2.8 & 2.8 & 2.8 & 2.8 & 2.8 & 2.8 \\
\hline E. coli & 0.4 & 3.0 & 3.0 & 3.0 & 3.0 & 3.0 & 3.0 & 0.4 & 2.0 & 2.5 & 3.0 & 3.0 & 3.0 & 3.0 \\
\hline C. albicans & 0.4 & 1.9 & 1.7 & 2.9 & 2.9 & 2.9 & 2.9 & 0.4 & 1.9 & 2.9 & 2.9 & 2.9 & 2.9 & 2.9 \\
\hline A. brasiliensis & -0.3 & -0.4 & -0.4 & 0.4 & 0.4 & 0.5 & 0.5 & -0.3 & -0.3 & -0.2 & 0.4 & 0.5 & 0.5 & 0.3 \\
\hline C. sporogenes & 1.0 & I.I & 1.2 & 1.2 & 1.4 & $\mathrm{I} .4$ & 1.4 & 1.0 & 0.9 & 1.0 & 1.3 & 1.4 & 1.5 & 1.3 \\
\hline \multirow[t]{2}{*}{ M. luteus } & -0.1 & 0.0 & 0.2 & 0.8 & $>2.9$ & $>2.9$ & $>2.9$ & -0.1 & 0.2 & 0.9 & 2.9 & 2.9 & 2.9 & 2.9 \\
\hline & \multicolumn{7}{|c|}{$2^{\circ} \mathrm{C}-8^{\circ} \mathrm{C}, \mathrm{SWI}$} & \multicolumn{7}{|c|}{$20^{\circ} \mathrm{C}-25^{\circ} \mathrm{C}, \mathrm{SWI}$} \\
\hline S. aureus & -0.1 & -0.6 & -0.7 & -0.2 & -0.2 & 0.2 & 1.2 & -0.1 & -0.8 & 0.2 & 1.3 & 2.9 & 2.9 & 2.9 \\
\hline P. aeruginosa & 0.2 & 2.8 & 2.8 & 2.8 & 2.8 & 2.8 & 2.8 & 0.2 & 2.8 & 2.8 & 2.8 & 2.8 & 2.8 & 2.8 \\
\hline E. coli & 0.0 & -0.5 & -0.1 & 0.4 & 1.3 & $>3.0$ & $>3.0$ & 0.0 & -0.2 & 1.7 & 1.8 & 1.9 & 1.9 & 2.1 \\
\hline C. albicans & 0.2 & 0.3 & I.I & 1.2 & 1.4 & $\mathrm{I} .4$ & 1.5 & 0.2 & 0.4 & 1.0 & 1.6 & 1.9 & 2.0 & 1.6 \\
\hline A. brasiliensis & -0.2 & -0.1 & -0.3 & -0.2 & 0.4 & 0.5 & 0.4 & -0.2 & -0.2 & -0.3 & 0.3 & 0.3 & 0.4 & 0.4 \\
\hline C. sporogenes & 0.7 & 0.8 & 1.0 & 1.0 & I.I & 1.1 & I.I & 0.7 & 0.8 & 0.9 & 1.0 & 1.0 & 1.0 & 1.0 \\
\hline M. luteus & -0.1 & 0.1 & 0.1 & 0.2 & 0.2 & 0.4 & 0.7 & -0.1 & 0.2 & 0.1 & 0.4 & 0.8 & 1.0 & 2.2 \\
\hline
\end{tabular}

Note: Average of $n=2$ is reported.

Abbreviations: SSI, sterile saline (sodium chloride 0.9\%) for injection; SWI, sterile water for injection; h, hours; d, days; S. aureus, Staphylococcus aureus; P. aeruginosa, Pseudomonas aeruginosa; E. coli, Escherichia coli; C. albicans, Candida albicans; A. brasiliensis, Aspergillus brasiliensis; C. sporogenes, Clostridium sporogenes; M. luteus, Micrococcus luteus. 
Table 5 Summary of log reductions with respect to initial time point for the low-level challenge test for epoprostenol sodium AS $1.5 \mathrm{mg}$ reconstituted and diluted to $15,000 \mathrm{ng} / \mathrm{mL}$ with SSI and SWI and stored at two different temperatures $\left(2^{\circ} \mathrm{C}-8^{\circ} \mathrm{C}\right.$ and $\left.20^{\circ} \mathrm{C}-25^{\circ} \mathrm{C}\right)$

\begin{tabular}{|c|c|c|c|c|c|c|c|c|c|c|c|c|c|c|}
\hline \multirow[t]{2}{*}{ Microorganism } & $\mathbf{O h}$ & $6 \mathrm{~h}$ & $24 \mathrm{~h}$ & $48 \mathrm{~h}$ & $72 \mathrm{~h}$ & $5 \mathrm{~d}$ & $10 \mathrm{~d}$ & $\mathbf{O h}$ & $6 \mathrm{~h}$ & $24 \mathrm{~h}$ & $48 \mathrm{~h}$ & $72 \mathrm{~h}$ & $5 \mathrm{~d}$ & $10 \mathrm{~d}$ \\
\hline & \multicolumn{7}{|c|}{$2^{\circ} \mathrm{C}-8^{\circ} \mathrm{C}, \mathrm{SSI}$} & \multicolumn{7}{|c|}{$20^{\circ} \mathrm{C}-25^{\circ} \mathrm{C}, \mathrm{SSI}$} \\
\hline S. aureus & -0.2 & 0.2 & 1.1 & 2.9 & 2.9 & 2.9 & 2.9 & -0.2 & 2.1 & 2.9 & 2.9 & 2.9 & 2.9 & 2.9 \\
\hline P. aeruginosa & 0.0 & 2.8 & 2.8 & 2.8 & 2.8 & 2.8 & 2.8 & 0.0 & 2.8 & 2.8 & 2.8 & 2.8 & 2.8 & 2.8 \\
\hline E. coli & 0.2 & 2.1 & 3.0 & 3.0 & 3.0 & 3.0 & 3.0 & 0.2 & 2.7 & 3.0 & 3.0 & 3.0 & 3.0 & 3.0 \\
\hline C. albicans & 0.5 & 1.9 & 2.9 & 2.9 & 2.9 & 2.9 & 2.9 & 0.5 & 0.8 & 2.9 & 2.9 & 2.9 & 2.9 & 2.9 \\
\hline A. brasiliensis & -0.3 & -0.3 & -0.3 & 0.5 & 0.5 & 0.5 & 0.3 & -0.3 & -0.3 & -0.3 & -0.2 & 0.1 & 0.2 & 0.2 \\
\hline C. sporogenes & 0.1 & 0.2 & 0.3 & 1.2 & 1.3 & 1.3 & 1.5 & 0.1 & 0.2 & 0.4 & 1.3 & 1.5 & 1.5 & $\mathrm{I} .4$ \\
\hline \multirow[t]{2}{*}{ M. luteus } & 0.2 & 0.4 & 0.5 & 1.4 & 2.9 & 2.9 & 2.9 & 0.2 & 0.2 & 0.9 & 2.9 & 2.9 & 2.9 & 2.9 \\
\hline & \multicolumn{7}{|c|}{$2^{\circ} \mathrm{C}-8^{\circ} \mathrm{C}, \mathrm{SWI}$} & \multicolumn{7}{|c|}{$20^{\circ} \mathrm{C}-25^{\circ} \mathrm{C}, \mathrm{SWI}$} \\
\hline S. aureus & -0.6 & -0.6 & -0.4 & -0.2 & -0.2 & 0.2 & 1.5 & -0.6 & -0.6 & 0.3 & 1.8 & 2.9 & 2.9 & 2.9 \\
\hline P. aeruginosa & -0.1 & 2.8 & 2.8 & 2.8 & 2.8 & 2.8 & 2.8 & -0.1 & 2.8 & 2.8 & 2.8 & 2.8 & 2.8 & 2.8 \\
\hline E. coli & 0.0 & -0.1 & 1.0 & 2.2 & 3.0 & 3.0 & 3.0 & 0.0 & 0.4 & 3.0 & 3.0 & 3.0 & 3.0 & 3.0 \\
\hline C. albicans & -0.3 & 0.6 & I.I & 1.3 & 1.3 & 1.6 & 1.9 & 0.3 & 0.5 & 0.9 & 1.5 & 1.6 & 2.4 & 2.4 \\
\hline A. brasiliensis & -0.4 & -0.4 & -0.2 & -0.2 & 0.0 & 0.2 & 0.3 & -0.4 & -0.3 & -0.4 & -0.3 & -0.3 & -0.3 & -0.3 \\
\hline C. sporogenes & 0.1 & 0.1 & 0.2 & 1.2 & 1.3 & 1.2 & I.I & 0.1 & 0.2 & 0.3 & 0.3 & 1.2 & 1.2 & 1.0 \\
\hline M. luteus & 0.1 & 0.1 & 0.2 & 0.2 & 0.2 & 0.2 & 0.7 & 0.1 & 0.1 & 0.2 & 0.2 & 0.7 & 1.0 & 1.2 \\
\hline
\end{tabular}

Note: Average of $\mathrm{n}=2$ is reported.

Abbreviations: SSI, sterile saline (sodium chloride $0.9 \%$ ) for injection; SWI, sterile water for injection; h, hours; d, days; S. aureus, Staphylococcus aureus; P. aeruginosa, Pseudomonas aeruginosa; E. coli, Escherichia coli; C. albicans, Candida albicans; A. brasiliensis, Aspergillus brasiliensis; C. sporogenes, Clostridium sporogenes; M. luteus, Micrococcus luteus.

A

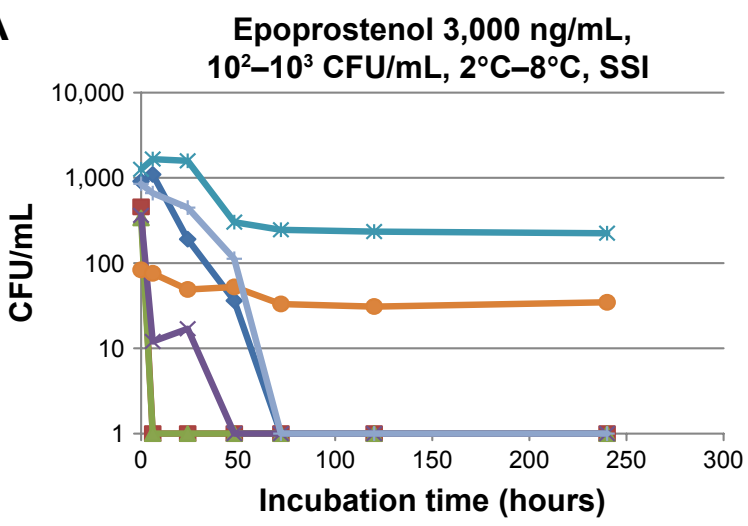

C
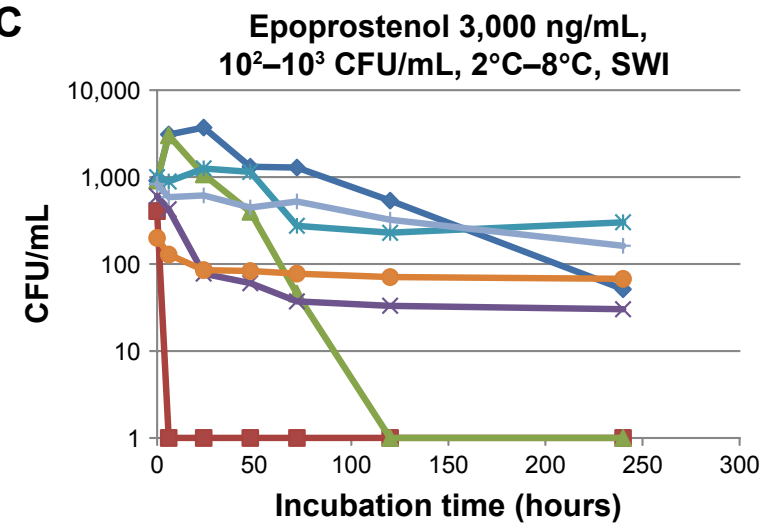

B Epoprostenol $3,000 \mathrm{ng} / \mathrm{mL}$, 10,000

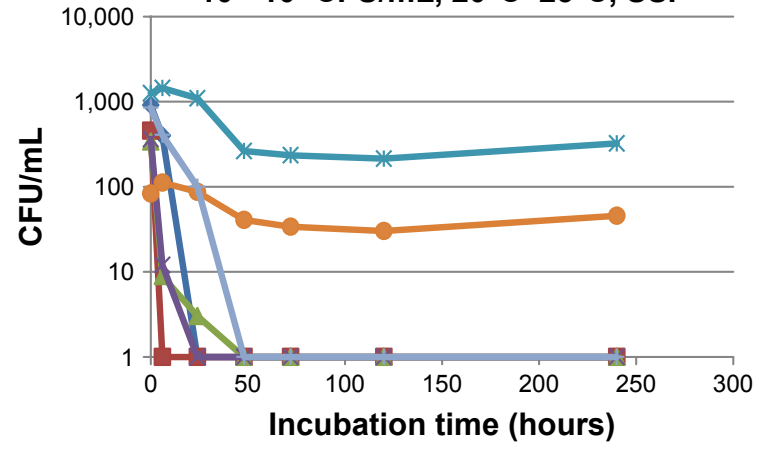

D Epoprostenol $3,000 \mathrm{ng} / \mathrm{mL}$,

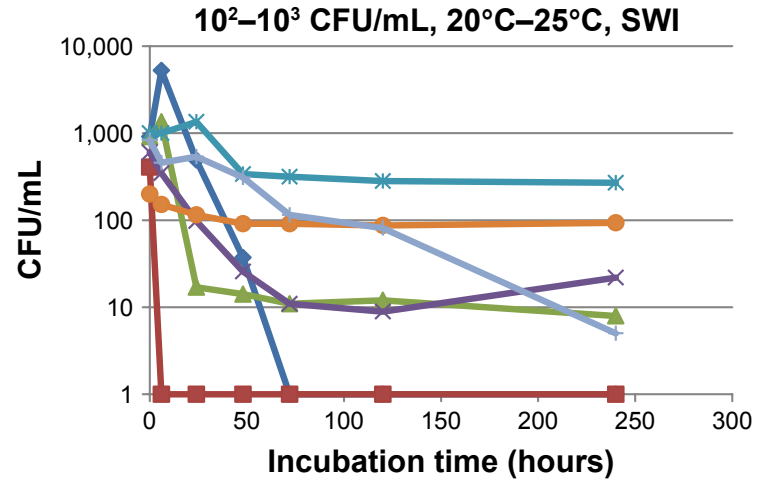

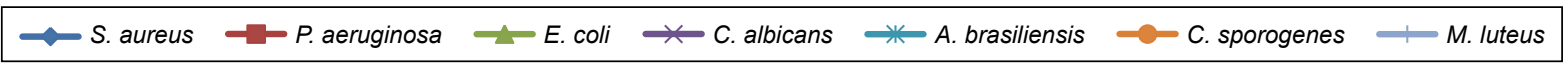

Figure I Microbial growth curves of low-level challenge test for epoprostenol sodium AS $0.5 \mathrm{mg}$ reconstituted and diluted to $3,000 \mathrm{ng} / \mathrm{mL}$ with $(\mathbf{A}) \mathrm{SSI}$ at $2^{\circ} \mathrm{C}-8^{\circ} \mathrm{C}$, (B) $\mathrm{SSI}$ at $20^{\circ} \mathrm{C}-25^{\circ} \mathrm{C}$, (C) SWI at $2^{\circ} \mathrm{C}-8^{\circ} \mathrm{C}$, and (D) SWI at $20^{\circ} \mathrm{C}-25^{\circ} \mathrm{C}$.

Note: Average of $n=2$ is reported.

Abbreviations: SSI, sterile saline (sodium chloride 0.9\%) for injection; SWI, sterile water for injection; CFU, colony forming units; S. aureus, Staphylococcus aureus; P. aeruginosa, Pseudomonas aeruginosa; E. coli, Escherichia coli; C. albicans, Candida albicans; A. brasiliensis, Aspergillus brasiliensis; C. sporogenes, Clostridium sporogenes; M. luteus, Micrococcus luteus. 



$\checkmark$ S. aureus $\rightarrow$ P. aeruginosa $\leftarrow$ E. coli $\longleftarrow$ C. albicans

Figure 2 Microbial growth curves of low-level challenge test for epoprostenol sodium AS $1.5 \mathrm{mg}$ reconstituted and diluted to I5,000 ng/mL with $(\mathbf{A}) \mathrm{SSI}$ at $2^{\circ} \mathrm{C}-8^{\circ} \mathrm{C}$, (B) $\mathrm{SSI}$ at $20^{\circ} \mathrm{C}-25^{\circ} \mathrm{C}$, (C) SWI at $2{ }^{\circ} \mathrm{C}-8^{\circ} \mathrm{C}$, and (D) SWI at $20^{\circ} \mathrm{C}-25^{\circ} \mathrm{C}$.

Note: Average of $n=2$ is reported.

Abbreviations: SSI, sterile saline (sodium chloride 0.9\%) for injection; SWI, sterile water for injection; CFU, colony forming units; S. aureus, Staphylococcus aureus; P. aeruginosa, Pseudomonas aeruginosa; E. coli, Escherichia coli; C. albicans, Candida albicans; A. brasiliensis, Aspergillus brasiliensis; C. sporogenes, Clostridium sporogenes; M. luteus, Micrococcus luteus.

concentrations in SSI. A slight increase in CFU was found at the beginning of the incubation period for $A$. brasiliensis and sometimes for $S$. aureus (Tables 4 and 5 and Figures 1A and $\mathrm{B}$ and $2 \mathrm{~A}$ and $\mathrm{B}$ ). This could be due to initial growth, potentially related to residual growth medium, or it could be that clusters of cells broke apart, thereby causing an increase in $\mathrm{CFU}$ on the plates. The same phenomenon was observed for the low-level challenge test using the diluent SWI at both storage temperatures and the $3,000 \mathrm{ng} / \mathrm{mL}$ concentration: an initial increase in CFU appeared for $S$. aureus and E. coli (Table 4 and Figure 1C and D). The results for S. aureus in SWI (Table 5) support the interpretation of cluster breakage, since higher counts were already observed at time zero, where growth cannot be the reason. Initial higher counts are known to appear in microorganisms such as Staphylococcus, Micrococcus, and the mold Aspergillus, where cells/spores tend to form clusters. ${ }^{20,21}$ For $S$. aureus, the effect was more pronounced in SWI than in SSI. The observed growth had reversed by the 48 -hour time point. A. brasiliensis and
C. sporogenes showed similar behavior to that seen with SSI: their number remained relatively constant or even increased slightly after 5 days. Likely, it is the result of spore formation for $C$. sporogenes or the presence of spores for A. brasiliensis, as bacterial spores are highly resistant to many antimicrobial active ingredients. In SWI, the CFU count of C. albicans - after an initial decrease - stayed constant and at $20^{\circ} \mathrm{C}-25^{\circ} \mathrm{C}$, even increased after 5 days (Figures $1 \mathrm{C}$ and $\mathrm{D}$ and $2 \mathrm{C}$ and $\mathrm{D}$ ), whereas in SSI, it died off within several hours at both $2^{\circ} \mathrm{C}-8^{\circ} \mathrm{C}$ and $20^{\circ} \mathrm{C}-25^{\circ} \mathrm{C}$ (Figures $1 \mathrm{~A}$ and $\mathrm{B}$ and $2 \mathrm{~A}$ and $\mathrm{B}$ ). In SWI, only two to three of the seven microorganisms died off completely (Figures $1 \mathrm{C}$ and D and 2C and D). P. aeruginosa died off almost instantaneously, whereas the remaining three microorganisms ( $S$. aureus, E. coli, and M. luteus) decreased at a slower rate than with SSI. In summary, for these three microorganisms and also for $C$. albicans, the reconstitution and further dilution of epoprostenol sodium AS with SWI had a lesser antimicrobial effect than with SSI. 
Table 6 Summary of log reductions with respect to initial time point for the high-level challenge test for epoprostenol sodium AS $0.5 \mathrm{mg}$ reconstituted and diluted to $3,000 \mathrm{ng} / \mathrm{mL}$ with SSI and SWI and stored at two different temperatures $\left(2^{\circ} \mathrm{C}-8^{\circ} \mathrm{C}\right.$ and $\left.20^{\circ} \mathrm{C}-25^{\circ} \mathrm{C}\right)$

\begin{tabular}{|c|c|c|c|c|c|c|c|c|c|c|c|c|c|c|}
\hline \multirow[t]{2}{*}{ Microorganism } & $\mathbf{O h}$ & $6 \mathrm{~h}$ & $24 \mathrm{~h}$ & $48 h$ & $72 \mathrm{~h}$ & $5 \mathrm{~d}$ & $10 \mathrm{~d}$ & $\mathbf{O h}$ & $6 \mathrm{~h}$ & $24 \mathrm{~h}$ & $48 \mathrm{~h}$ & $72 \mathrm{~h}$ & $5 \mathrm{~d}$ & $10 \mathrm{~d}$ \\
\hline & \multicolumn{7}{|c|}{$2^{\circ} \mathrm{C}-8^{\circ} \mathrm{C}, \mathrm{SSI}$} & \multicolumn{7}{|c|}{$20^{\circ} \mathrm{C}-25^{\circ} \mathrm{C}, \mathrm{SSI}$} \\
\hline S. aureus & 0.0 & -0.2 & 0.2 & 0.5 & 2.2 & 4.3 & 5.0 & 0.0 & 0.5 & 4.2 & 6.0 & 6.0 & 6.0 & 6.0 \\
\hline P. aeruginosa & 1.4 & 5.9 & 5.9 & 5.9 & 5.9 & 5.9 & 5.9 & $\mathrm{I} .4$ & 5.9 & 5.9 & 5.9 & 5.9 & 5.9 & 5.9 \\
\hline E. coli & 1.4 & 3.8 & 4.7 & 6.0 & 6.0 & 6.0 & 6.0 & $\mathrm{I} .4$ & 3.6 & 4.1 & 6.0 & 6.0 & 6.0 & 6.0 \\
\hline C. albicans & -0.1 & -0.2 & 0.4 & 1.6 & 1.7 & 2.7 & 3.8 & -0.1 & 0.0 & 0.8 & 2.3 & 3.0 & 3.9 & 4.1 \\
\hline A. brasiliensis & -0.2 & -0.4 & 0.1 & I.I & 1.1 & 1.2 & 1.1 & -0.2 & -0.3 & 0.6 & 0.7 & I.I & 1.2 & 0.2 \\
\hline C. sporogenes & 0.2 & 0.3 & 1.0 & 1.0 & I.I & 1.1 & 0.3 & 0.2 & 0.2 & 0.8 & 0.8 & 0.8 & 0.8 & 0.4 \\
\hline \multirow[t]{2}{*}{ M. luteus } & 0.0 & 0.0 & 0.4 & 0.8 & 1.2 & 3.4 & 4.4 & 0.0 & 0.4 & 1.9 & 3.9 & 4.6 & 6.0 & 6.0 \\
\hline & \multicolumn{7}{|c|}{$2^{\circ} \mathrm{C}-8^{\circ} \mathrm{C}, \mathrm{SWI}$} & \multicolumn{7}{|c|}{$20^{\circ} \mathrm{C}-25^{\circ} \mathrm{C}, \mathrm{SWI}$} \\
\hline S. aureus & 0.0 & -0.5 & -0.2 & -0.1 & 0.0 & 0.1 & 0.1 & 0.0 & 0.0 & 0.3 & 1.0 & 1.2 & 2.2 & 3.8 \\
\hline P. aeruginosa & 2.1 & 5.9 & 5.9 & 5.9 & 5.9 & 5.9 & 5.9 & 2.1 & 5.9 & 5.9 & 5.9 & 5.9 & 5.9 & 5.9 \\
\hline E. coli & 0.0 & 0.0 & 0.7 & I.I & 2.5 & 4.1 & 5.5 & 0.0 & 0.3 & 3.4 & 4.7 & 5.1 & 4.4 & 5.9 \\
\hline C. albicans & -0.1 & -0.1 & -0.2 & 0.3 & 0.4 & 0.7 & 0.3 & -0.1 & -0.2 & 0.1 & 0.8 & 0.9 & 1.5 & -0.5 \\
\hline A. brasiliensis & -0.3 & -0.3 & 0.3 & 0.4 & 0.4 & 0.5 & 0.3 & -0.3 & -0.2 & 0.3 & 1.3 & 1.3 & 1.4 & 0.6 \\
\hline C. sporogenes & 0.2 & 0.2 & 0.8 & 0.8 & 0.8 & 0.8 & 0.3 & 0.2 & 0.2 & 0.2 & 0.4 & 0.6 & 0.6 & 0.1 \\
\hline M. luteus & 0.0 & 0.3 & 0.6 & 0.7 & 0.8 & 0.8 & 0.8 & 0.0 & 0.3 & 0.5 & 0.7 & 0.7 & 0.8 & 1.0 \\
\hline
\end{tabular}

Note: Average of $n=2$ is reported.

Abbreviations: SSI, sterile saline (sodium chloride 0.9\%) for injection; SWI, sterile water for injection; h, hours; d, days; S. aureus, Staphylococcus aureus; P. aeruginosa, Pseudomonas aeruginosa; E. coli, Escherichia coli; C. albicans, Candida albicans; A. brasiliensis, Aspergillus brasiliensis; C. sporogenes, Clostridium sporogenes; M. luteus, Micrococcus luteus.

\section{High-level challenge tests}

The log reductions for the high-level challenge tests (ie, the incubation with $10^{5}-10^{6} \mathrm{CFU}$ ) of the epoprostenol sodium AS solutions are summarized in Tables 6 and 7. Growth curves are depicted in Figures 3 and 4.

A comparable picture was seen for the high-level challenge test as for the low-level test. When using SSI as a diluent, the acceptance criterion of USP 51 was fulfilled at every time point. With the exceptions of $A$. brasiliensis and $C$. sporogenes, the remaining five microorganisms died off or at least strongly declined by day 10. P. aeruginosa died off almost instantaneously in SSI, but for the other microorganisms, kinetics of the decline were slower compared with the low-level challenge test. A. brasiliensis and C. sporogenes again showed a decline until day 5 but then remained stable or started growing slightly. With SWI as a diluent, the picture

Table 7 Summary of log reductions with respect to initial time point for the high-level challenge test for epoprostenol sodium AS $1.5 \mathrm{mg}$ reconstituted and diluted to $15,000 \mathrm{ng} / \mathrm{mL}$ with SSI and SWI and stored at two different temperatures $\left(2^{\circ} \mathrm{C}-8^{\circ} \mathrm{C}\right.$ and $\left.20^{\circ} \mathrm{C}-25^{\circ} \mathrm{C}\right)$

\begin{tabular}{|c|c|c|c|c|c|c|c|c|c|c|c|c|c|c|}
\hline \multirow[t]{2}{*}{ Microorganism } & $\mathbf{O h}$ & $6 \mathrm{~h}$ & $24 \mathrm{~h}$ & $48 h$ & $72 \mathrm{~h}$ & $5 d$ & $10 \mathrm{~d}$ & $\mathbf{O h}$ & $6 \mathrm{~h}$ & $24 \mathrm{~h}$ & $48 \mathrm{~h}$ & $72 \mathrm{~h}$ & $5 d$ & $10 \mathrm{~d}$ \\
\hline & \multicolumn{7}{|c|}{$2^{\circ} \mathrm{C}-8^{\circ} \mathrm{C}, \mathrm{SSI}$} & \multicolumn{7}{|c|}{$20^{\circ} \mathrm{C}-25^{\circ} \mathrm{C}, \mathrm{SSI}$} \\
\hline S. aureus & 0.0 & 0.3 & 0.8 & 1.6 & 2.4 & 4.4 & 6.0 & 0.0 & 0.4 & 0.7 & 2.7 & 4.6 & 5.7 & 6.0 \\
\hline P. aeruginosa & 0.7 & 5.9 & 5.9 & 5.9 & 5.9 & 5.9 & 5.9 & 0.7 & 5.9 & 5.9 & 5.9 & 5.9 & 5.9 & 5.9 \\
\hline E. coli & 0.9 & 6.0 & 6.0 & 6.0 & 6.0 & 6.0 & 6.0 & 0.9 & 6.0 & 6.0 & 6.0 & 6.0 & 6.0 & 6.0 \\
\hline C. albicans & -0.1 & -0.1 & 1.4 & 1.9 & 2.9 & 4.3 & 4.6 & -0.1 & -0.1 & 1.4 & 2.5 & 2.8 & 4.0 & 5.5 \\
\hline A. brasiliensis & 0.2 & 0.2 & 1.5 & 1.5 & 1.5 & $\mathrm{I} .4$ & 0.5 & 0.2 & 0.1 & 0.3 & 0.3 & 0.3 & 0.5 & 0.4 \\
\hline C. sporogenes & 0.0 & 0.0 & 0.3 & 0.9 & 0.9 & 1.0 & 1.5 & 0.0 & 0.2 & 0.5 & 0.7 & 0.9 & 1.2 & 1.3 \\
\hline \multirow[t]{2}{*}{ M. luteus } & 0.0 & -0.5 & -0.5 & 1.0 & 2.2 & 4.0 & 4.7 & 0.0 & 0.4 & 1.9 & 3.5 & 4.1 & 5.2 & 5.7 \\
\hline & \multicolumn{7}{|c|}{$2^{\circ} \mathrm{C}-8^{\circ} \mathrm{C}$, SWI } & \multicolumn{7}{|c|}{$20^{\circ} \mathrm{C}-25^{\circ} \mathrm{C}, \mathrm{SWI}$} \\
\hline S. aureus & 0.0 & 0.0 & -0.2 & 0.2 & 0.2 & 0.4 & 1.1 & 0.0 & 0.0 & 0.3 & 1.5 & 2.9 & 4.1 & 4.8 \\
\hline P. aeruginosa & 0.0 & 5.9 & 5.9 & 5.9 & 5.9 & 5.9 & 5.9 & 0.0 & 5.9 & 5.9 & 5.9 & 5.9 & 5.9 & 5.9 \\
\hline E. coli & 0.0 & 0.4 & 1.3 & 2.0 & 4.0 & 6.0 & 6.0 & 0.0 & 0.9 & 1.2 & 3.3 & 4.0 & 4.0 & 0.9 \\
\hline C. albicans & -0.1 & 0.0 & -0.2 & 0.0 & 0.3 & 0.7 & 2.5 & -0.1 & -0.3 & 0.1 & 0.6 & 0.9 & 1.8 & 1.8 \\
\hline A. brasiliensis & 0.1 & 0.2 & 0.4 & 0.5 & 0.5 & 0.6 & 0.3 & 0.1 & 0.3 & 0.5 & 0.5 & 0.5 & 1.0 & 0.4 \\
\hline C. sporogenes & 0.1 & 0.2 & 0.5 & 0.7 & 0.7 & 0.8 & 0.4 & 0.1 & 0.1 & 0.1 & 0.4 & 0.5 & 0.5 & I.I \\
\hline M. luteus & 0.0 & 0.4 & 0.4 & 0.4 & 0.5 & 0.5 & 0.8 & 0.0 & 0.1 & 0.4 & 0.4 & 0.7 & 0.8 & 1.0 \\
\hline
\end{tabular}

Abbreviations: SSI, sterile saline (sodium chloride 0.9\%) for injection; SWI, sterile water for injection; h, hours; d, days; S. aureus, Staphylococcus aureus; P. aeruginosa, Pseudomonas aeruginosa; E. coli, Escherichia coli; C. albicans, Candida albicans; A. brasiliensis, Aspergillus brasiliensis; C. sporogenes, Clostridium sporogenes; M. luteus, Micrococcus luteus. 
A
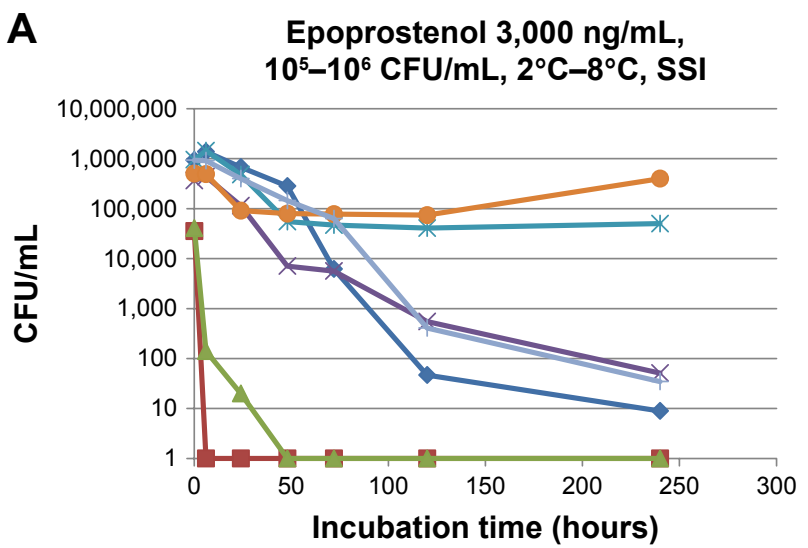

C

Epoprostenol 3,000 ng/mL, $10^{5}-10^{6} \mathrm{CFU} / \mathrm{mL}, 2^{\circ} \mathrm{C}-8^{\circ} \mathrm{C}, \mathrm{SWI}$

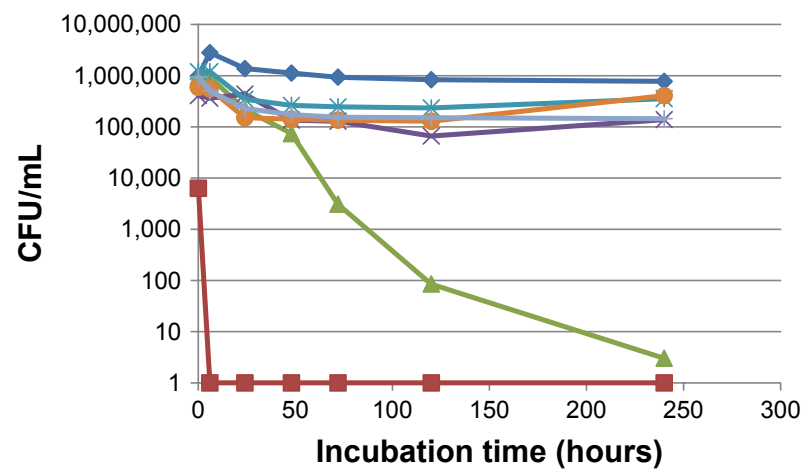

B Epoprostenol $3,000 \mathrm{ng} / \mathrm{mL}$,

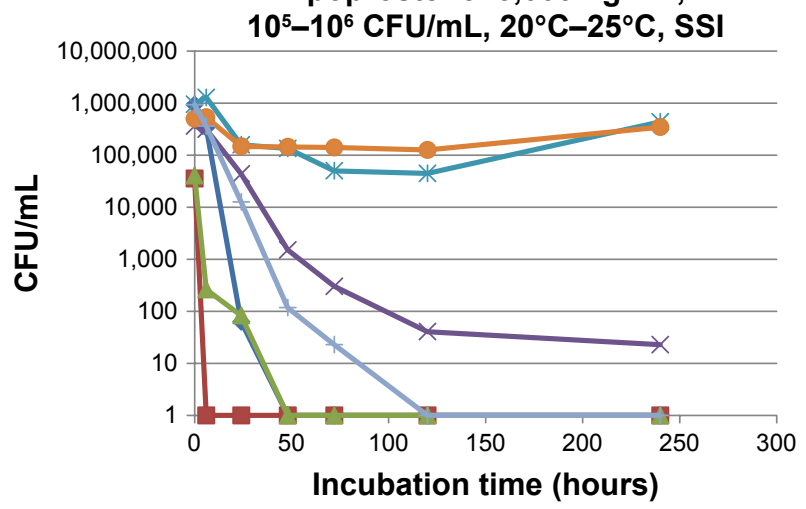

D

Epoprostenol 3,000 ng/mL,

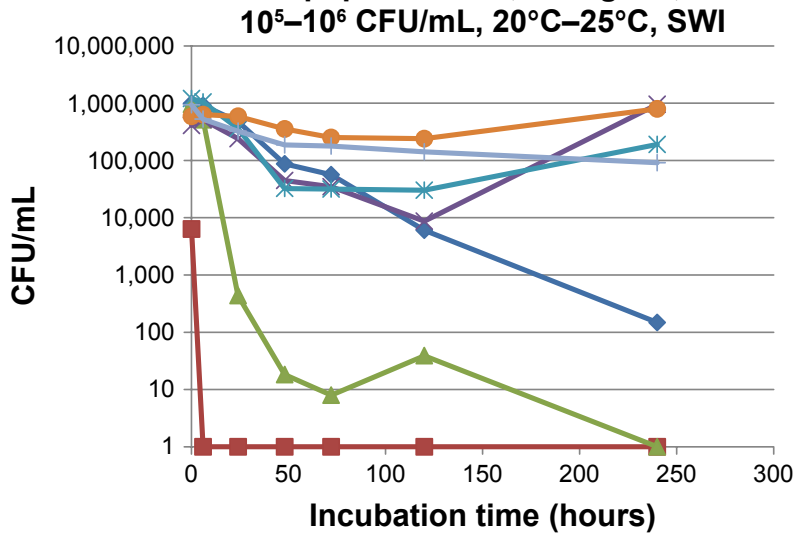

$\multimap$ S. aureus $\leftarrow$ P. aeruginosa $\leftarrow$ E. coli $\leftarrow$ C. albicans $\leftarrow$ A. brasiliensis $\leftarrow$ C. sporogenes - M. luteus

Figure 3 Microbial growth curves of high-level challenge test for epoprostenol sodium AS $0.5 \mathrm{mg}$ reconstituted and diluted to $3,000 \mathrm{ng} / \mathrm{mL}$ with $(\mathbf{A}) \mathrm{SSI}$ at $2^{\circ} \mathrm{C}-8^{\circ} \mathrm{C}$, (B) SSI at $20^{\circ} \mathrm{C}-25^{\circ} \mathrm{C}$, (C) $\mathrm{SWI}$ at $2^{\circ} \mathrm{C}-8^{\circ} \mathrm{C}$, and (D) $\mathrm{SWl}$ at $20^{\circ} \mathrm{C}-25^{\circ} \mathrm{C}$.

Note: Average of $n=2$ is reported.

Abbreviations: SSI, sterile saline (sodium chloride 0.9\%) for injection; SWl, sterile water for injection; CFU, colony forming units; S. aureus, Staphylococcus aureus; P. aeruginosa, Pseudomonas aeruginosa; E. coli, Escherichia coli; C. albicans, Candida albicans; A. brasiliensis, Aspergillus brasiliensis; C. sporogenes, Clostridium sporogenes; M. luteus, Micrococcus luteus.

was slightly more complex. $P$. aeruginosa died off almost instantaneously. E. coli died off with the exception of $20^{\circ} \mathrm{C}-25^{\circ} \mathrm{C}$ at $15,000 \mathrm{ng} / \mathrm{mL}$, where after day 5 , it increased almost to its initial level (Figure 4D). The remaining five microorganisms remained relatively constant at $2^{\circ} \mathrm{C}-8^{\circ} \mathrm{C}$, whereas at $20^{\circ} \mathrm{C}-25^{\circ} \mathrm{C}, \mathrm{S}$. aureus showed a strong decline.

\section{Discussion}

Microbial challenge testing for epoprostenol sodium AS solutions was conducted across a time range consistent with the demonstrated stability of the product and reflecting likely clinical use. ${ }^{4}$ Storage at a temperature of $20^{\circ} \mathrm{C}-25^{\circ} \mathrm{C}$ was assessed to mimic average temperatures found in temperate and Mediterranean countries (climatic zones I and II). ${ }^{22}$ Since patients or caregivers have the option to prepare epoprostenol sodium AS solutions in advance and store them in the refrigerator prior to use for up to 8 days, a storage temperature of $2^{\circ} \mathrm{C}-8^{\circ} \mathrm{C}$ was also evaluated.

\section{Effect of storage temperature}

A storage temperature of $2^{\circ} \mathrm{C}-8^{\circ} \mathrm{C}$ or $20^{\circ} \mathrm{C}-25^{\circ} \mathrm{C}$ did not have a strong effect on the growth of the tested microorganisms. As described earlier, the epoprostenol sodium AS solutions inhibited all challenged microorganisms. Therefore, we expected a lesser inhibitory effect at $2^{\circ} \mathrm{C}-8^{\circ} \mathrm{C}$ since microorganisms normally start growth earlier at $20^{\circ} \mathrm{C}-25^{\circ} \mathrm{C}$ than at $2^{\circ} \mathrm{C}-8^{\circ} \mathrm{C}$. However, such an effect was not found, suggesting that epoprostenol sodium AS had an inhibitory effect on microorganisms independent of their stage of growth. Despite investigating higher inocula in the current study, these findings were in line with previously reported results using an inoculum of $<10^{1} \mathrm{CFU} / \mathrm{mL}^{4}{ }^{4}$

\section{Effect of reconstitution diluent}

Bearing in mind that neither epoprostenol sodium AS nor the diluents (SSI and SWI) contain any preservative, any antimicrobial activity could in theory be caused by antimicrobial 
A

A

Epoprostenol $15,000 \mathrm{ng} / \mathrm{mL}$, $10^{5}-10^{6} \mathrm{CFU} / \mathrm{mL}, 2^{\circ} \mathrm{C}-8^{\circ} \mathrm{C}, \mathrm{SSI}$

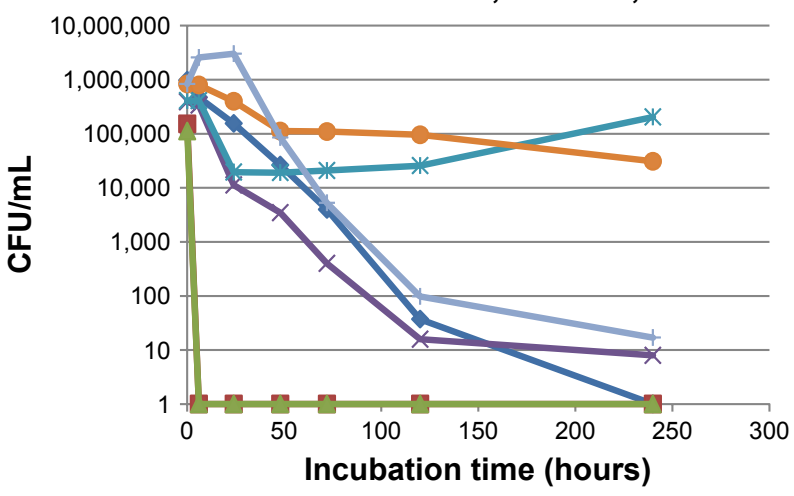

C
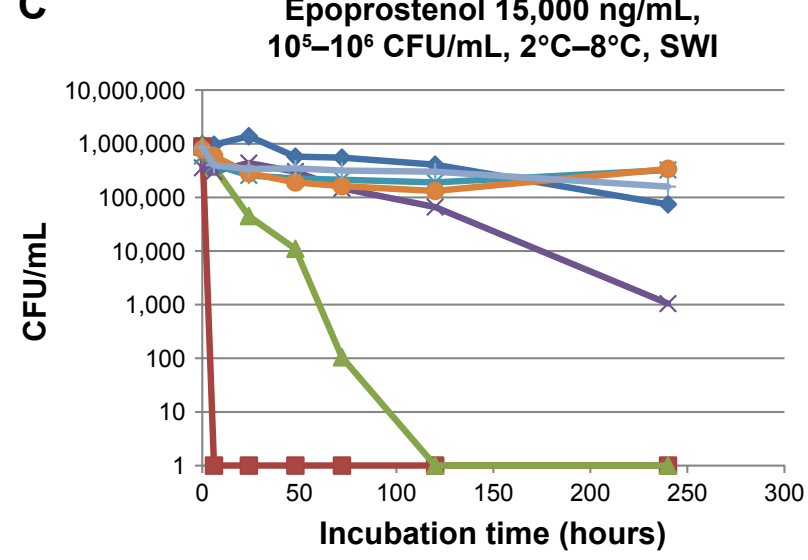

B

Epoprostenol 15,000 ng/mL, $10^{5}-10^{6} \mathrm{CFU} / \mathrm{mL}, 20^{\circ} \mathrm{C}-25^{\circ} \mathrm{C}$, SSI

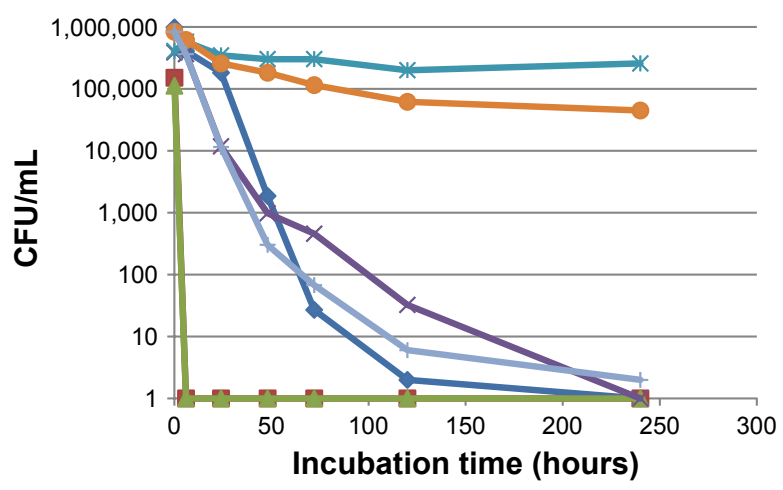

D Epoprostenol $15,000 \mathrm{ng} / \mathrm{mL}$, $10^{5}-10^{6} \mathrm{CFU} / \mathrm{mL}, 20^{\circ} \mathrm{C}-25^{\circ} \mathrm{C}$, SWI

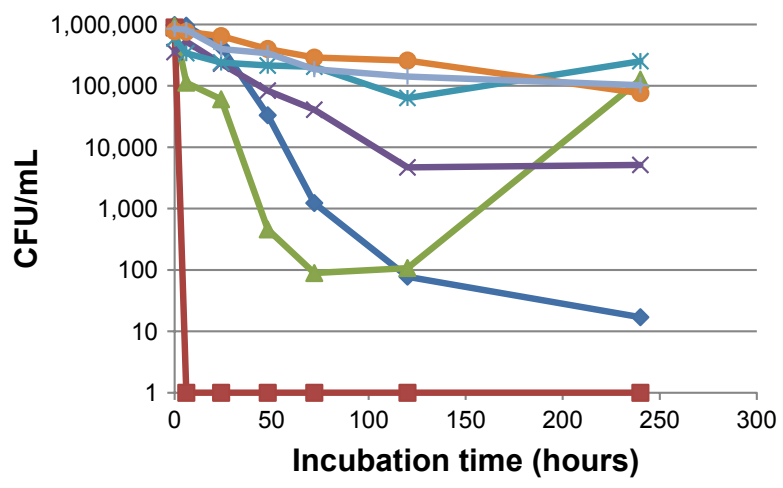

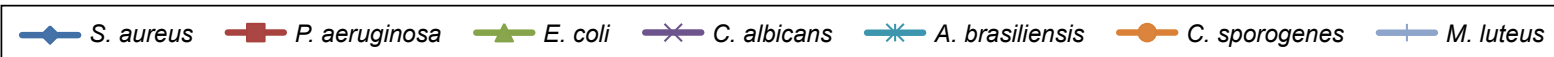

Figure 4 Microbial growth curves of high-level challenge test for epoprostenol sodium AS I.5 $\mathrm{mg}$ reconstituted and diluted to I5,000 ng/mL with $(\mathbf{A}) \mathrm{SSI}$ at $2^{\circ} \mathrm{C}-8^{\circ} \mathrm{C}$, (B) $\mathrm{SSI}$ at $20^{\circ} \mathrm{C}-25^{\circ} \mathrm{C},(\mathbf{C}) \mathrm{SWI}$ at $2^{\circ} \mathrm{C}-8^{\circ} \mathrm{C}$, and (D) SWI at $20^{\circ} \mathrm{C}-25^{\circ} \mathrm{C}$.

Note: Average of $n=2$ is reported.

Abbreviations: SSI, sterile saline (sodium chloride 0.9\%) for injection; SWI, sterile water for injection; CFU, colony forming units; S. aureus, Staphylococcus aureus; P. aeruginosa, Pseudomonas aeruginosa; E. coli, Escherichia coli; C. albicans, Candida albicans; A. brasiliensis, Aspergillus brasiliensis; C. sporogenes, Clostridium sporogenes; M. luteus, Micrococcus luteus.

activity of epoprostenol itself or by the relatively high $\mathrm{pH}$ values resulting from arginine and $\mathrm{NaOH}$ present in the formulation. Evidence on antimicrobial activity of epoprostenol is contradictory. ${ }^{23} \mathrm{~A}$ control experiment using a placebo solution may clarify this further.

In all experiments performed, the diluent SSI had a stronger inhibitory effect than SWI. One possible interpretation could be that microorganisms in a $0.9 \%$ saline solution are more comfortable and enter a growth stage, whereas in water, the osmotic pressure affects their growth negatively. With growth, ie, cell division, the microorganisms were more susceptible to the low $\mathrm{pH}$ or the antimicrobial activity of epoprostenol and consequently die off. It is worth noting that epoprostenol sodium AS is administered through a $0.2 \mu \mathrm{m}$ filter; this filtration greatly increases patient safety.

\section{Conclusion}

No microbial growth with respect to the initial microbial count was observed for any of the tested organisms in epoprostenol sodium AS solutions at 3,000 $\mathrm{ng} / \mathrm{mL}$ and $15,000 \mathrm{ng} / \mathrm{mL}$, using either SSI or SWI as diluents, for two different levels of inoculum $\left(10^{2}-10^{3} \mathrm{CFU} / \mathrm{mL}\right.$ and $10^{5}-10^{6} \mathrm{CFU} / \mathrm{mL}$ ), and following up to 10 days of storage at $2{ }^{\circ} \mathrm{C}-8^{\circ} \mathrm{C}$ or $20^{\circ} \mathrm{C}-25^{\circ} \mathrm{C}$. The microorganisms tested represented a broad spectrum of potential manufacturing, nosocomial, and household contaminants, including gramnegative and gram-positive bacteria, common yeast, and mold. Results varied with respect to the type of microorganism, with some microorganisms dying off completely and others remaining overall stable or returning to initial levels. The study furthermore showed that epoprostenol sodium 
AS had an inhibitory effect on microorganisms that was independent of their stage of growth as no dependence with respect to storage temperature $\left(2^{\circ} \mathrm{C}-8^{\circ} \mathrm{C}\right.$ or $\left.20^{\circ} \mathrm{C}-25^{\circ} \mathrm{C}\right)$ was observed. The choice of diluent (SSI versus SWI) did influence the growth kinetics in a sense that SSI had a stronger inhibitory effect than SWI. The results confirm that, even with higher inocula than tested previously, epoprostenol sodium AS, when reconstituted and diluted, does not support the growth of microorganisms.

\section{Acknowledgment}

Editorial support was provided by ApotheCom, UK, and the study was funded by Actelion Pharmaceuticals Ltd.

\section{Disclosure}

Dirk Bandilla, Paolo Giudici, and Olivier Lambert are employees of Actelion Pharmaceuticals Ltd. Marcel Goverde was a paid consultant for Actelion Pharmaceuticals Ltd. The authors report no other conflicts of interest in this work.

\section{References}

1. Farber HW, Loscalzo J. Pulmonary arterial hypertension. $N$ Engl J Med. 2004;351(16):1655-1665.

2. Humbert M, Sitbon O, Simonneau G. Treatment of pulmonary arterial hypertension. $N$ Engl J Med. 2004;351(14):1425-1436.

3. Actelion Pharmaceuticals L. Veletri (epoprostenol for injection); 2016. Available from: https://www.veletri.com/pdf/veletri_full_prescribing_ information_2nd_gen.pdf. Accessed February, 2017.

4. Lambert $\mathrm{O}$, Bandilla D. Stability and preservation of a new formulation of epoprostenol sodium for treatment of pulmonary arterial hypertension. Drug Des Devel Ther. 2012;6:235-244.

5. Lambert O, Bandilla D, Iyer R, Witchey-Lakshmanan L, Palepu N. Stability and microbiological properties of a new formulation of epoprostenol sodium when reconstituted and diluted. Drug Des Devel Ther. 2012;6:61-70

6. United States Pharmacopoeia. The US Pharmacopeial Convention [homepage on the Internet]. 2017. Available from: http://www.usp.org/. Accessed February, 2017.

7. Gu Z, Parra C, Wong A, Nguyen A, Cheung R, Catalano T. Postreconstitution stability of telavancin with commonly used diluents and intravenous infusion solutions. Curr Ther Res Clin Exp. 2015;77: $105-110$.
8. Cuvas Apan O, Apan TZ, Apan A. In vitro antimicrobial activity of commonly used vasoactive drugs. J Clin Anesth. 2016;34:407-411.

9. Findley K, Oh J, Yang J, et al. Topographic diversity of fungal and bacterial communities in human skin. Nature. 2013;498(7454):367-370.

10. Grice EA, Kong HH, Conlan S, et al. Topographical and temporal diversity of the human skin microbiome. Science. 2009;324(5931): $1190-1192$.

11. Kloos WE, Musselwhite MS. Distribution and persistence of Staphylococcus and Micrococcus species and other aerobic bacteria on human skin. Appl Microbiol. 1975;30(3):381-385.

12. Munk K. Mikrobiologie. Heidelberg-Berlin: Spektrum Akademischer Verlag; 2001.

13. Madigan M, Martinko J. Brock Biology of Microorganisms. 11 ed. Upper Saddle River, NJ: Prentice Hall; 2009.

14. Ayliffe GA, Babb JR, Quoraishi AH. A test for 'hygienic' hand disinfection. J Clin Pathol. 1978;31(10):923-928.

15. Hall GS, Mackintosh CA, Hoffman PN. The dispersal of bacteria and skin scales from the body after showering and after application of a skin lotion. J Hyg. 1986;97(2):289-298.

16. Hof H, Dörries R. Medizinische Mikrobiologie. 4th ed. 2009. Georg Thieme Verlag KG, Stuttgart, Germany.

17. Selwyn S, Ellis H. Skin bacteria and skin disinfection reconsidered. Br Med J. 1972;1(5793):136-140.

18. Metcalfe J. Microbiological quality of drug products after penetration of the container system for dose preparation prior to patient administration. Am Pharm Rev. 2009;12(1):84-89.

19. Quisno R, Gibby IW, Foter MJ. A neutralizing medium for evaluating the germicidal potency of the quaternary ammonium salts. Am J Pharm Sci Support Public Health. 1946;118(9):320-323.

20. Gotz F, Bannerman T, Schleifer K-H. The genera Staphylococcus and Macrococcus. In: Dworkin M, Falkow S, Rosenberg E, Schleifer K-H, Stackebrandt E, editors. The Prokaryotes. 3rd ed. New York, NY: Springer Science+Business Media, LLC; 2006:5-75.

21. Kocur M, Kloos W, Schleifer K-H. The genus Micrococcus. In: Dworkin M, Falkow S, Rosenberg E, Schleifer K-H, Stackebrandt E, editors. The Prokaryotes. 3rd ed. New York, NY: Springer Science+ Business Media, LLC; 2006:961-971.

22. World Health Organization. WHO Expert Committee on Specifications for Pharmaceutical Preparations (WHO Technical Report Series, No. 953); 2009. Available from: http://apps.who.int/iris/ bitstream/10665/44553/1/WHO_TRS_953_eng.pdf. Accessed July $24,2017$.

23. Lieb J. The immunostimulating and antimicrobial properties of lithium and antidepressants. $J$ Infect. 2004;49(2):88-93.

\section{Publish your work in this journal}

Drug Design, Development and Therapy is an international, peerreviewed open-access journal that spans the spectrum of drug design and development through to clinical applications. Clinical outcomes, patient safety, and programs for the development and effective, safe, and sustained use of medicines are the features of the journal, which

\section{Dovepress}

has also been accepted for indexing on PubMed Central. The manuscript management system is completely online and includes a very quick and fair peer-review system, which is all easy to use. Visit http://www.dovepress.com/testimonials.php to read real quotes from published authors. 